4. Мануэль Агилар-Морено. Ацтеки. Энциклопедический справочник. Москва: Вече, 2011. 544c.

5. Скульптура ацтеків. URL: https://uk.wikipedia.org/ wiki/\%D0\%A1\%D0\%BA\%D1\%83\%D0\%BB\%D1\%8C\%D0\%BF\%D1\%82 $\% \mathrm{D} 1 \% 83 \% \mathrm{D} 1 \% 80 \% \mathrm{D} 0 \% \mathrm{~B} 0 \_\% \mathrm{D} 0 \% \mathrm{~B} 0 \% \mathrm{D} 1 \% 86 \% \mathrm{D} 1 \% 82 \% \mathrm{D} 0 \% \mathrm{~B} 5 \% \mathrm{D} 0 \%$ BA\%D1\%96\%D0\%B2

6. Воины-орлы. URL: https://warriors.fandom.com/ru/wiki/\%D0\%92\% D0\%BE\%D0\%B8\%D0\%BD\%D1\%8B-\%D0\%BE\%D1\%80\%D0\%BB\% $\mathrm{D} 1 \% 8 \mathrm{~B}$

7. Власов Д.М., Винничук М.С. Особливості проектування чоловічих прикрас в етнічному стилі на основі вивчення культури Мексики. Наукові розробки молоді на сучасному етапі: тези доповідей XVIII Всеукраїнської наукової конференції молодих вчених та студентів, 18, 19 квітня 2019 р. Київ : Київський національний університет технологій та дизайну, 2019. Т. 1. С. 129-130.

DOI https://doi.org/10.30525/978-9934-26-004-9-104

\title{
ЗАСТОСУВАННЯ ТЕХНІКИ РІЗЬБЛЕННЯ ДЛЯ СТВОРЕННЯ ОБ'ЄКТІВ ЛЕНД-АРТУ
}

Гальчинська О. С.

аспірантка факультету дизайну

Гула Є. П.

професор

завідувач кафедри рисунка та живопису

Пашкевич К. Л.

доктор технічних наук, професор, професор кафедри ергономіки і дизайну

Базелюк Н. Л.

аспірантка факультету дизайну

Київського національного університету технологій та дизайну

м. Київ, Украӥна

Під час реалізації творчих задумів, художники ленд-арту вдаються до різноманітних дизайнерських прийомів і технік, серед яких широко застосовуються техніки декоративно-ужиткового мистецтва: плетіння [2], дротарство, різьблення, каменярство тощо. Серед митців ленд-арту 
користується популярністю техніка різьблення по дереву, яка являє собою одну з найдавніших і найбільш поширених на теренах України техніку. Принцип створення робіт полягає у знятті певного шару матеріалу за допомогою спеціальних інструментів. Цей метод може бути застосований до будь-якого виду деревини, тобто матеріалу, який достатньо міцний, щоб утримувати форму при його обробці, та водночас м'який щоб з ним можна було працювати і є невід'ємною складовою українського мистецтва, етнічної художньої культури.

Традиційно роботу 3 деревиною прадавні майстри широко застосовували для створення предметів побуту, елементів оздоблення інтер'єру, меблів, архітектурних споруд, засобів пересування та судноплавства, церковного убранства тощо. Відповідно, сучасні митці користуються досвідом народних промислів: теслярства, столярства, бондарства, стельмаства, різьблення тощо (табл. 1).

Творчість митця ленд-арту зі Швейцарії - Урса-Пітера Твельмана (Urs-Peter Twellmann) заснована на інтелектуальному дослідженні деревини-сировини, як матеріалу та ії фізичних можливостей [3].

Таблиця 1

Застосування традиційних деревообробних промислів

\begin{tabular}{|c|c|c|c|}
\hline $\begin{array}{c}\text { Об'єкт } \\
\text { дизайну }\end{array}$ & $\begin{array}{l}\text { Tехніка } \\
\text { виготов- } \\
\text { лення }\end{array}$ & Зображення & $\begin{array}{l}\text { Функціональне } \\
\text { призначення, } \\
\text { застосування }\end{array}$ \\
\hline Меблі & Столярство & & $\begin{array}{c}\text { Утилітарно- } \\
\text { естетичне, } \\
\text { художньо- } \\
\text { декоративне. } \\
\text { Вироби } \\
\text { повсякденного } \\
\text { вжитку, які } \\
\text { застосовуються в } \\
\text { побуті, інтер'єрі } \\
\text { та екстер'єрі. } \\
\end{array}$ \\
\hline $\begin{array}{c}\text { Засоби } \\
\text { пересування }\end{array}$ & $\begin{array}{c}\text { Стельмаств } \\
\text { о }\end{array}$ & & $\begin{array}{c}\text { Утилітарно- } \\
\text { функціональне, } \\
\text { побутове. Вироби } \\
\text { широкого вжитку, } \\
\text { транспортні } \\
\text { засоби та їх } \\
\text { елементи, } \\
\text { застосовувались в } \\
\text { побуті, торговій та } \\
\text { культурній сферах } \\
\text { тощо. }\end{array}$ \\
\hline
\end{tabular}




\begin{tabular}{|c|c|c|c|}
\hline $\begin{array}{c}\text { Архітектурн } \\
\text { і споруди, } \\
\text { малі } \\
\text { архітектурні } \\
\text { форми }\end{array}$ & Теслярство & 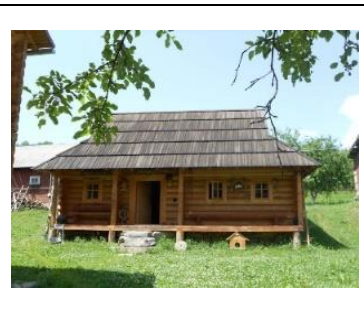 & $\begin{array}{c}\text { Утилітарно- } \\
\text { функціональне, } \\
\text { культурно- } \\
\text { побутове, } \\
\text { художньо- } \\
\text { декоративне. } \\
\text { Житло, релігійні } \\
\text { та господарські } \\
\text { споруди тощо. }\end{array}$ \\
\hline Посуд & Бондарство & & $\begin{array}{c}\text { Утилітарно- } \\
\text { естетичне, } \\
\text { художньо- } \\
\text { декоративне. } \\
\text { Використовуютьс } \\
\text { я в побуті як } \\
\text { предмети } \\
\text { господарського } \\
\text { вжитку, декор } \\
\text { інтер'єру. } \\
\end{array}$ \\
\hline $\begin{array}{c}\text { Скульптури, } \\
\text { декоративні } \\
\text { фігури, } \\
\text { декор храмів }\end{array}$ & Різьблення & $\lim _{i=1}$ & $\begin{array}{c}\text { Художньо- } \\
\text { декоративне, } \\
\text { утилітарно- } \\
\text { естетичне, } \\
\text { функціональне. } \\
\text { Твори мистецтва, } \\
\text { декор інтер'єру, } \\
\text { іграшки, предмети } \\
\text { обрядового, } \\
\text { релігійного та } \\
\text { декоративного } \\
\text { вжитку тощо. } \\
\end{array}$ \\
\hline
\end{tabular}

Його досвід роботи 3 матеріалом та розроблена митцем техніка обробки деревини та різьблення різноманітними сучасними приладами, дозволяють йому виготовляти твори, які демонструють філігранну майстерність і тяжіють до видозміни сприйняття вихідного матеріалу. Спиляні стовбури дерев художник описує як процес «відкриття», оскільки спили демонструють різноманітність сприйняття розміру дерев та конкретних порід деревини. В своїх творах Твельманн розрізає ялиновий стовбур із гілками на найтонші подовжні зрізи; графічно розпилює гілки верби на маленькі циліндри; видовбує в стовбурах великих дерев циліндричні отвори та робить надрізи. За рахунок використання різних підходів в обробці ленд-арту, утворюється декоративна гра світла і тіні, яку демонструють такі роботи, що дозволяє сприймати деревину з іншої точки зору. Одним $з$ таких ленд-арт творів митця $є$ «Смерекове кільце» 
(Anneau D`epicea) (Швейцарія, 2002 р.) (рис. 1, б), в якому митець поєднав різні фактури деревини: тонкі гілки та напівкруглі зрізи стовбурів смереки. Цей арт-об'єкт створений у формі кільця, загальний об'єм якого наповнений гілками, що розходяться від центру, як промені, а контури формують рівні, заокруглені зрізи стовбуру.

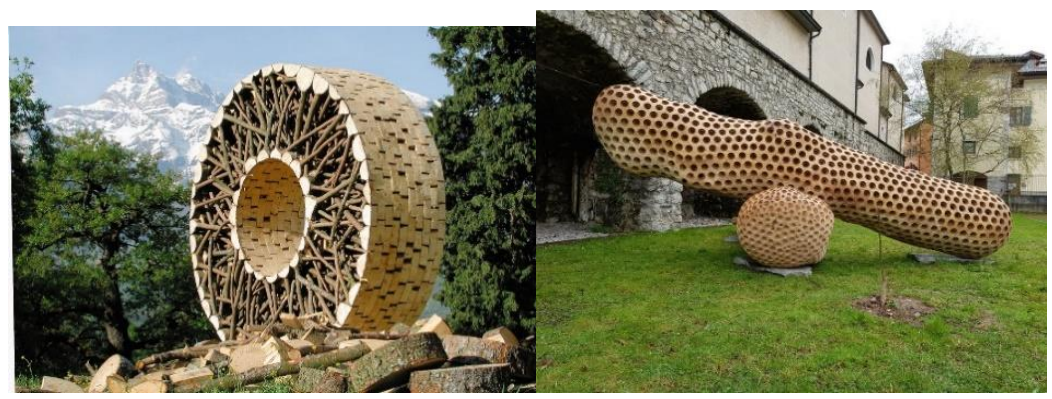

a)

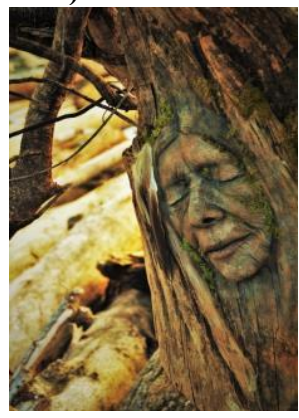

B)

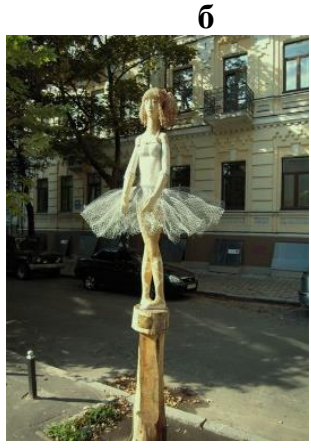

г)

Рис. 1. Твори ленд-арт в техніці різьблення: a - «Смерекове кільце» (Anneau D`epicea) У.П. Твельмана, Швейцарія, 2002 р.; б - «Розбитий дуб» (The broken oak) С. І. Фроста, м. Борго-Валсугана, Італія, 2019 р; в - «Бабуся Верба» (Grandmother Willow) Д. Берньє, м. Вікторія, Канада 2017 р.; г «Дерев'яна Балерина» К. Скритуцького, м. Київ, Україна 2009 р.

Митці ленд-арту використовують широкий діапазон сучасних технічних прийомів в поєднанні 3 традиційними [1]. Серед таких $\epsilon$ Стюарт Іан Фрост (Stuart Ian Frost) з Великої Британії. Він створює свої арт-об'єкти за концепцією, коли місце, в якому буде знаходитися твір, $\epsilon$ 
домінуючим фактором для втілення ідеї [4]. Він працює переважно 3 деревиною, яка походить 3 даної місцевості, що надає ій ідентичності та приналежності до місцевого середовища. Наприклад, митець використовує засохлі стовбури дерев, гілки, тирсу, або рештки виробництва. Характерними ознаками для творів Фроста $є$ їх незвична, відчужена для локації, в якій вони розташовані, форма, а також зміни структури об'єкта за рахунок різьблення, перфорації, оздоблення візерунками. Впроваджуючи даний підхід Фрост створив художній твір 3 дубу, що був повалений внаслідок бурі, на тому ж місці, де він ріс. Лендарт «Розбитий дуб» (The broken oak), розташований у підніжжя гори Артеселла (м. Борго-Валсугана, Італія, 2019 р.). Ленд-арт виконаний 3 використанням технічного прийому - перфорації дерева круглими, однаковими за розміром отворами з метою продемонструвати силу стихії та слабкість могутнього дубу (рис. 1, а).

Аналізуючи різьблення в ленд-арті слід зауважити творчість відомої канадської художниці Дебори Берньє (Debra Bernier), яка працює 3 засохлими деревами та корчами, що дрейфували у воді і були викинуті хвилями на берег водойми. Її ленд-арт філософія полягає у відновленні та наданні нового, часом фантастичного образу матеріалу, тобто прагнення надати нового життя старому матеріалу [5]. Мисткиня переважно працює з корчами, або дрейфуючою деревиною, яку збирає на узбережжі водойм, з яких створює чисельні арт-об'єкти у вигляді міфічних персонажів, фей, русалок тощо. Твір Дебори Берньє «Бабуся Верба» (Grandmother Willow) м. Вікторія, Канада 2017 р. (рис. 3, в), вирізьблений з великого корча та оздоблений мохом, демонструє образ старої жінки, що вписаний в стовбур дерева. Даний об’єкт ленд-арту підкреслює важливість старіння, як етапу життя людини, набуття нею досвіду і мудрості 3 роками. Тобто концепція твору - відобразити мудрість, накопичену з часом, провести паралелі між матеріалом старою деревиною та об'єктом, відтвореним 3 нього.

Подібний творчий підхід, але з відмінною концепцією використовує в своїх роботах український митець, Костянтин Скритуцький [6]. Його ленд-арт об'єкти мають на меті - збереження старих засохлих дерев в київських подвір'ях. В творчому доробку скульптора $є$ кілька артоб'єктів в м. Києві, створених з засохлих дерев, які підлягали знищенню: «Бабки на дереві» 2007 р.; «Літаючий крокодил, що зловив необачну рибу» 2007 р.; «Їжачок в тумані» 2009 р. та інші. Твір К. Скритуцького «Дерев'яна Балерина» 2009 р. (рис. 4, г), виготовлений 3 липи, що засохла і підлягала знищенню, руки і голова зроблені з кераміки, а спідниця - пачка з будівельної сітки, яка додає декоративного ефекту, виблискуючи на сонці. 
Таким чином, серед митців ленд-арту спостерігаються тенденції звернення до надбання мистецької спадщини значною мірою зумовлені використанням техніки різьблення як джерела глибинних історикокультурних традицій.

\title{
Лiтература:
}

1. Imperadori M., Clozza M., Vanossi A., Brunone F. Digital Design and Wooden Architecture for Arte Sella. Digital Transformation of the Design, Construction and Management Processes of the Built Environment. 2020. C. 161-173. DOI: 10.1007/978-3-030-33570-0_15

2. Гальчинская О., Васильева Е., Пашкевич К. Использование техники плетения из природных материалов в искусстве ленд-арт. Revista de științe socioumane. Chişinău, 2020. Nr.1(44). C. 95-106. URL: https://ibn.idsi.md/ro/vizualizare_articol/109949 (Last accessed: 11.11.2020).

3. Сайт Urs-Peter Twellmann URL: https://twellmann.ch/portfolio/ outdoor-sculptures/ (Last accessed: 11.11.2020).

4. Сайт Stuart Ian Frost. URL: https://stuartianfrost.com (Last accessed: 9.11.2020).

5. Сайт Debra Bernier URL: https://www.facebook.com/ShapingSpirit (Last accessed: 11.11.2020).

DOI https://doi.org/10.30525/978-9934-26-004-9-105

\section{ІНКЛЮЗИВНИЙ ДИЗАЙН У МОДІ ХХІ СТОЛІТТЯ: СОЦІОКУЛЬТУРНІ, ЕТИЧНІ ТА ХУДОЖНІ АСПЕКТИ}

\author{
Дерман Л. М. \\ кандидат філософських наук, дочент, \\ завідувач кафедри дизайну та реклами \\ факультету філософії та суспільствознавства \\ Національного педагогічного університету імені М. П. Драгоманова \\ м. Київ, Украӥна \\ Розвиток інклюзивного дизайну бере свій початок у XX столітті. \\ Історія його виникнення та еволюції пов'язана 3 наслідками, що \\ принесли дві світові війни та розвиток науки, медицини, що дозволило \\ суттєво продовжити життя людей, в тому числі й тих, хто мав \\ фізіологічні порушення: опорно-рухової системи, сенсорної тощо.
}

